\title{
Existence of a Single Population of Hilsa Shad (Tenualosa Ilisha) With Low Genetic Variation in Bangladesh Waters Revealed by Cross-Species Gene Enrichment Method
}

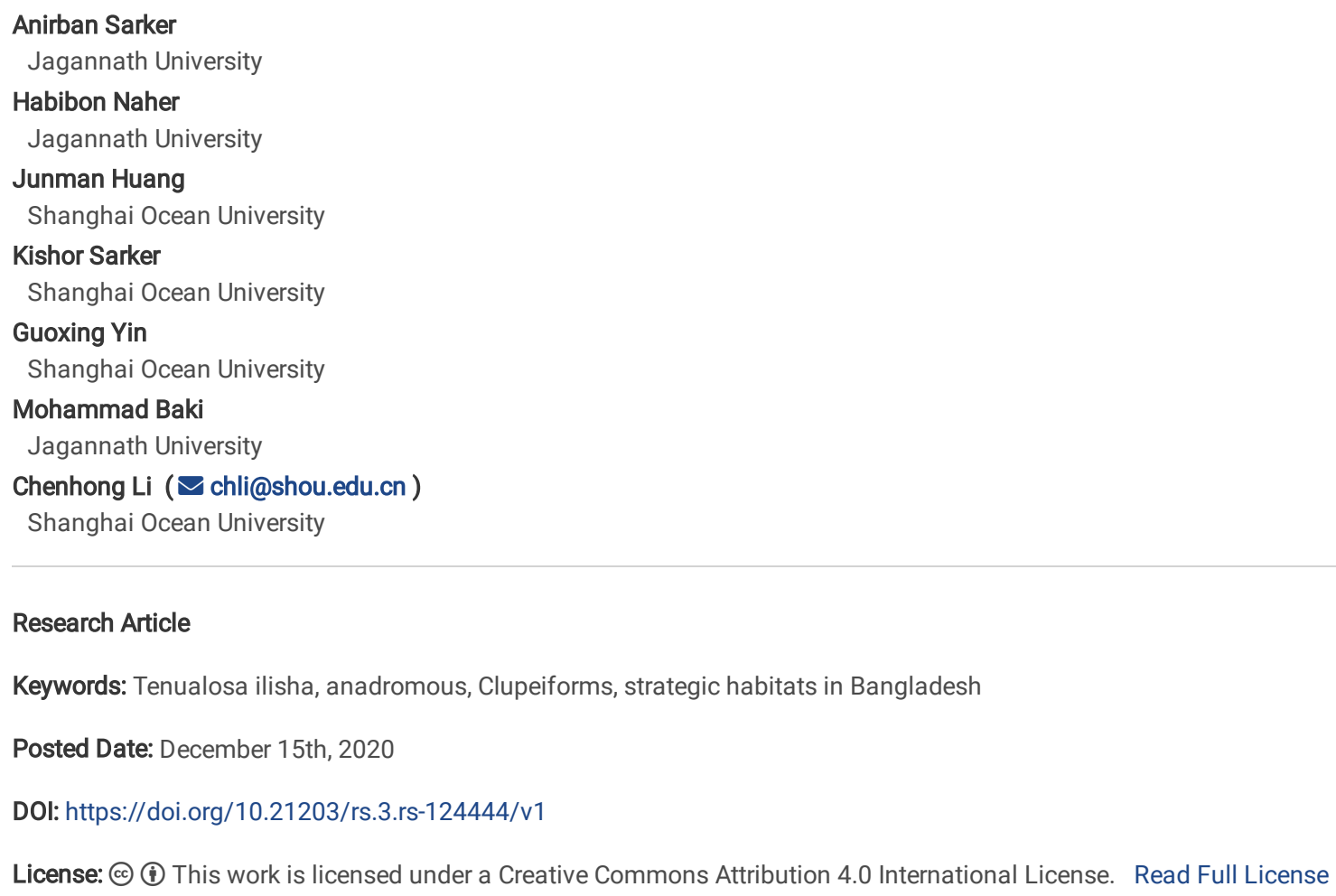




\section{Abstract}

Tenualosa ilisha is a popular anadromous and significant trans-boundary fish. For sustainable management and conservation of this fish, drawing an appropriate picture reflecting population status of this species is very essential based on their all-strategic habitats in Bangladesh. In this study, 139 samples from 18 sites were collected and cross-species gene enrichment method was applied to discover the exact population status of the fish. Like most of the Clupeiforms, nucleotide diversity and variation of this shad were very low. Population differences between most of the locations were low and not significant. However, $P$ values of a few locations were significant $(P<0.05)$ but their pairwise $F_{S T}$ values were very poor, which is inadequate to recognize any local populations. Structure analysis, PCA and maximum likelihood IQtree all indicated the presence of a single population in the Bangladesh water with some admixture individuals, which may contain partial genes from other populations. In the ML IQtree and Network, most of the individuals were mixed without showing any precise grouping, which might due to their highly migratory nature. Fishes from special type of habitats, e.g., haors, small coastal rivers etc. were not unique and no genetic differences between migratory cohorts were found.

\section{Introduction}

The national fish of Bangladesh, the Hilsa shad (Tenualosa ilisha Hamilton, 1822) (Family: Clupeidae) (Fig. 1) is a well-liked anadromous fish species ${ }^{1}$, locally known as llish. This is a significant trans-boundary fish that survives in the Bay of Bengal and migrates between marine and freshwater for breeding, nursing and feeding purposes. Bangladesh enjoys major share of this migrating fish from the Bay of Bengal to upstream rivers (86\%), followed by India ( $8 \%$ ), and Myanmar (4\%) ${ }^{2}$. The species is also distributed in Iran, Iraq, Saudi Arabia, Kuwait, Qatar, Oman, UAE, Pakistan, Sri Lanka, Thailand, Malaysia and Vietnam ${ }^{3}$. It is the largest single species fishery contributing $44 \%$ of total catch in Bangladesh that accounts virtually about $12.09 \%$ of total fish production of the country, representing around $1 \%$ of the total gross domestic product of the country with annual catch of 517,189 metric tons (inland catch: $232,698 \mathrm{MT}$ and Marine catch: $284,500 \mathrm{MT})^{4}$. Hilsa shad also remains a subsistence food for many poor coastal communities and a valuable resource for millions of people in the Bay of Bengal and its major associated river systems.

Discovery of population genetic structure and genetic diversity are very important for sustainable ocean fisheries, which can provide basic information for the fisheries resource assessment and management ${ }^{13}$. Due to environmental changes, pollution and over exploitation, many fishes are losing genetic diversity currently ${ }^{14}$. Previous studies on genetic population structure of $T$. ilisha were mostly based on allozymes, allele frequencies, microsatellite DNA markers and mitochondrial DNA regions: Cytochrome b (CytB), ATPase $6 \& 8$ (ATPase), $12 \mathrm{~s}$ and $16 \mathrm{~s}$ rRNA ${ }^{10,15-18}$. Mitochondrial gene analysis indicated temporal stability of sampled populations; with low genetic differentiation between temporal samples from same locality of three Indian rivers ${ }^{10}$. Very recently, A study discover the population genomics and structure of Hilsa shad in Bangladesh waters based on six and eight locations respectively using NextRAD sequencing ${ }^{19,20}$. But their studied locations did not represent overall water bodies of Bangladesh, like lentic water (haor) , hill stream river (e.g., Someshwari river) and small coastal rivers (i.e., Pashur river, Kocha river, Lata Chapli river and Tetulia river) including the middle portion of Bangladesh (e.g., Manikganj, Bhairab etc.) and south eastern portion of the Bay of Bengal. According to these studies, Hilsa population was divided into two genetically structured clusters, marine and estuarine and fresh water, based on their local adaptation. Finally, the riverine population was divided into north-western riverine (turbid freshwater) and the northeastern riverine (clear fresh water) clusters. They drawn several specific populations or clusters in the upper streams of Bangladesh, however, this shad is not found in the freshwater all over the year round. All of the spawning grounds of this shad were discovered in the lower stretches of the Meghna River and some other small coastal rivers situated almost in the same area ${ }^{6,21}$. Moreover, as a highly migratory species, Hilsa shad population should not able to make different clusters in their migratory routes. In the present study, sufficient number of samples were collected from almost all tactical water ecosystems including all major rivers of Bangladesh (i.e., the Padma, the Meghna, the Jamuna and the Brahmaputra river ), coastal waters of the Bay of Bengal (western and eastern) and its estuary (in total 18 locations). Locations also included previously unfocused lentic water (haor), hill stream river and small coastal rivers including the middle portion of Bangladesh. Moreover, samples were collected from seasonal migratory (i.e., summer vs. winter) cohorts. Our assumption is that, in order to draw the total picture of population of the Hilsa shad, sampling should be focused on diverse habitat types including all strategic ecosystems and migratory cohorts instead of different river sections of the same major drainages. .

We collected sequence data of 4,434 nuclear genes from 139 Hilsa samples taken from the Bay of Bengal, its' estuaries and all possible lotic and lentic waters and two migratory cohorts, applying a cross-species gene enrichment method ${ }^{22}$, to examine the genetic diversity and population structure of this shad. Our goal is to provide a solid estimation of the population status of Hilsa shad using genome-wide data and to infer its genetic diversity. Our study will provide a comprehensible look into the genetic diversity of this commercially important species and an evaluation of its population genetic structure. The findings should be important for the management and conservation of this important fisheries resource.

\section{Material And Methodology}

Sample collection and DNA extraction. Study species is a common food fish in Bangladesh. Samples (dead fish) have been taken from commercial fishing boats or directly from fisherman at fish landing. Fish tissue sampling and protocols were approved by the 'Ethics Committee for the Use of Animal Subjects' of Shanghai Ocean University, China. One hundred thirty-nine individuals of Hilsa shad were collected from diverse ecosystems of Bangladesh including 18 locations involved all fresh water, brackish and marine habitats for this fish. Furthermore, three primary routes of migration of Hilsa shad from Bay of Bengal were also considered. These sampling locations were categorized into seven different habitat groups based on their habitat nature i.e., 1.Western Riverine (Freshwater) 2.Eastern Riverine (Freshwater) 3.Haor and hill stream river 4.Middle Meghna 5.Meghna Estuary 6.Small Coastal Rivers (Estuary) 7.Bay of Bengal (Fig. 2, Table 1). The samples were identified based on morphological features ${ }^{23,24}$. Closely related five Kelee shad, Hilsa kelee were collected from Arabian Sea coast for using as out-group. For sampling, muscles were collected from the base of dorsal fin and fin clips were collected from the tip of caudal fin. For fixation and preservation of tissue samples, $100 \%$ and $95 \%$ ethanol were used respectively. Finally, samples were stored in $4^{0} \mathrm{C}$ refrigerator until DNA 
extraction started. DNA was extracted from $25 \mathrm{mg}$ of tissue using an Ezup DNA extraction kit following the protocol of the manufacturer (Sangon Biotech, Shanghai, China).

DNA library preparation, gene capture and sequencing. Extracted genomic DNA was sheared to about 500 bp using Covaris M220 Focused-ultrasonicator (Woburn, Massachusetts, USA) according to the manufacturer' instructions. Size of sheared DNA and product of every further step was measured by using agarose gel electrophoresis. DNA libraries were constructed and "with-beads" method was adopted in this protocol to obtain higher yield ${ }^{22}$. Inline indices were added to the adapter to label the samples in the ligation step of library preparation to ease the possible risk of cross contamination among the samples during subsequent gene capture step. After that library, products were pooled together equimolarly.

A cross species gene capture was done and genes were captured for two consecutive trials that increase the recovery rate of enriched gene ${ }^{22}$. A bait set was designed based on the sequence of Clupeiform species Denticeps clupeoides and Ilisha elongata for capturing highest number of genes. The enriched libraries were amplified by IS4 and indexing primers ${ }^{25}$. Finally, captured genes were pooled in equimolar ratios for sequencing on Illumina HiSeq X10 lane at Annoroad Inc (Beijing, China).

Data preparation read assembly and post assembly processing. According to the description in Assexon pipeline ${ }^{26}$, data processing, read assembly and post assembly processing were done. Raw reads from each sample were parsed according to their 8bp barcodes on P7 adapter using bcl2fastq v1.8.3 (IIlumina). Trim galore v0.4.1 (http://www.bioinformatics.babraham.ac.uk/projects/trim_galore/) was used to trim low quality bases and sequence adaptors. Coding frame of each marker sequence was predicted and corrected using a Perl script (predict_frames.pl). Coding sequences were extracted and translated into amino acid sequences by using Bio:: Seq module in Bioper| ${ }^{27}$.

PCR duplicates were excluded by using "-fastx_uniques" command in USEARCH v10.0.24028. Sequence of Danio rerio (https://doi.org/10.5061/dyrad.2j5b4) was used as a reference sequence to parse reads to each gene file. Reads were sorted to references with BLAST hit using UBLAST with a relaxed e-value of $1 \times 10^{-4}$. Reads of each locus were assembled (De novo assembly) into contigs by a conservative assembler SGA ${ }^{29}$. Contigs were locally aligned to protein sequences of references using the "protein $2 \mathrm{dna}$ " model in the package under Exonerate ${ }^{30}$. Reciprocal blast method was used to pick up the orthologous genes.

The output amino acid (AA) sequences were aligned in batch using MAFFTv7.369b ${ }^{31}$. The AA sequences were translated back to DNA after alignment. Poor and badly aligned sequences in coding regions were removed by filter.pl to avoid interfere in phylogenetic inference. Summary statistics (e.g., number of enriched samples, GC content and percentage of missing data) for coding and flanking region of each locus and sample was extracted by using statistics.pl ${ }^{26}$.

SNP calling. A custom Perl script was used to make consensus sequences for each target locus from assembled contigs ${ }^{26}$ and then reads with adapter sequences were trimmed and low quality reads were excluded and finally mapped to the consensus by using BWA v0.7.5. The sequence map format (SAM) files were converted into binary format (BAM) by using Samtools ${ }^{32}$. SNP sites were genotyped based on the BAM files using GATK-3.2.2 ${ }^{33}$. GATK Best Practices recommendations were followed ${ }^{34}$. Single SNP per locus with least amount of missing data and highest quality score was kept for most analyses to meet the requirement of linkage equilibrium. Custom Perl script was used again to convert the SNP VCF file into NEXUS file and STRUCTURE input file ${ }^{26}$.

Phylogenetic analysis and Network based on gene-capture data. A concatenated maximum likelihood (ML) tree was reconstructed under IQtree v1.6.9 with 1,000 bootstrap replicates using the aligned DNA sequences ${ }^{35}$. FigTree.v1.4.4 was used to visualize the consequential phylogenetic tree (http://tree.bio.ed.ac.uk/software/figtree/). Model selection and data partition were also automatically done by IQtree v1.6.9.

Network 5.0.1.1 ${ }^{36}$ was used to visualize genetic clustering of the individuals of different populations by making a median-joining network. To build the network, only 842 polymorphic sites were used. VCF2RDF converter was used to convert SNP VCF to .rdf file for using as an input file in Network analysis.

Genetic variation analysis. SNP vcf file was converted into arlequin (.arp) file using PGDspider 2.1.1.2 with the input of population summary ${ }^{37}$. SNP arlequin (.arp) file was used as an input file in the analysis of molecular variance (AMOVA), which was performed using ARLEQUIN 3.5.2 with 10,000 permutations ${ }^{38}$. Nucleotide diversity for each population was computed by using DnaSP v6.12.03 ${ }^{39}$. The SNP data of variant call format (.vcf) was used as an input file in DnaSP. Pairwise $\mathrm{F}_{\mathrm{ST}}$ matrix ${ }^{40}$ supported by ARLEQUIN 3.5.2 was used to calculate the genetic variation among groups, among populations within groups and within populations. Text editor Notepad+ was used to edit the project file at the time of AMOVA and $\mathrm{F}_{\mathrm{ST}}$ analysis.

Population clustering. Genetic Partitioning of the 139 individuals was assessed using STRUCTURE v2.3.4 $4^{41}$ based on the data containing only one SNP per locus. Initial burn was set in 50,000 replicates, followed by 500,000 replicates for each K (number of genetic clusters) for the STRUCTURE runs. The analysis were run for $\mathrm{K}=1-18$ (1-total number of locations), each replicated three times. Best $\mathrm{K}$ was identified by STRUCTURE HARVESTER $0.693^{42}$. Finally, result of STRUCTURE with best $\mathrm{K}$ was transferred to plot form. Principle Component Analyses (PCA) was computed in R environment by using the ADE4 R package 43 . SNP VCF file was filtered by using Vcftools 0.1 .15 (https://vcftools.github.io/) for using as an input file in PCA computation. Only 512 SNP sites less than $2 \%$ missing data were used for PCA analysis. Values of pc1 and pc 2 were plotted to draw the genetic clustering of individuals from different populations.

\section{Results}

Sequencing results (NGS). Each sample produced 4,015,989 raw reads on average and then 4,000,188 filtered reads (on average) were obtained from raw reads after trimming off adapter sequences and reads with low quality score $(\mathrm{Q}<20)$. After removing the 230,829 reads (on average) of $P C R$ duplicates, $93.87 \%$ of filtered reads were scrutinized as unique reads (3,769,359 on average). From each sample 1,395 target loci were obtained on average with the best one had 
2,223 loci and the lowest one had 504 captured loci (Table S1). The average number of captured loci of the out-group sample was 1,104. All loci (3,399 loci) of studied species and out-group were checked manually. Loci with weird segments, samples from only one location or with lower than four samples were also excluded. After exclusions, 2,461 loci were kept.

Phylogenetic relationships based on genome-scale nuclear data. The maximum likelihood tree was built using IQtree on all of the individuals of Bangladesh waters, collected from different ecosystems mixed together. No location had any unique cluster, but some portion of phylogenetic tree had partial groupings

(Fig. 3). The phylogenetic tree revealed that the Hilsa shad represent a single genetic population in the Bangladesh water and there is no significant cluster. In network of 842 SNP loci, all samples were randomly interconnected together without any type of pattern (Fig. 4). There is no isolation based on distance, water quality, nature of the habitat and migratory seasons. Negligible samples of same location showed inter-connections among them. That means network result also supported the presence of single population in Bangladesh water like the assumption depicted from maximum likelihood IQtree.

Genetic diversity and differentiation. Average nucleotide diversity (Pi) of Hilsa shad of Bangladesh water was 0.004632 , with highest value in Chilmari (0.008811) and lowest in Balashi Ghat (0.001809) (Table 3). Analysis of molecular variance (AMOVA) represented that percentage of variation among suspected significant habitat groups (i.e., Western riverine freshwater, Eastern riverine freshwater, haor and hill stream river, Middle Meghna freshwater, Meghna river estuary, small coastal rivers, the Bay of Bengal) was very low (0.99\%). Percentage of variations of among population within groups and within populations were $1.07 \%$ and $97.93 \%$ respectively (Table 2). Pairwise $F_{S T}$ values of maximum locations were very poor $\left(61 \% F_{S T}\right.$ value was in between 0.0009 $0.0993,2 \% F_{S T}$ value was more than that value and rest showed negative value) and most of the case, $P$ value was not significant. Populations of fresh water rivers (Western turbid and eastern clean rivers) also had poor $F_{S T}$ value and non significant $P$ value except between Manik Ganj (MG) and Chilmari (CM), which was more than significant level $(P<0.05)$ (Table 4). Populations of main migratory route and alternative migratory route had some differences. Samples of the Kocha river (PP) of alternative migratory route were different from all of the locations of main migratory route in the downstream (i.e., $\mathrm{CF}, \mathrm{MP}$, $\mathrm{BL}$ and $\mathrm{CP}$ ) based on significant $P$ value $(P<0.05)$ and samples of another alternative route location $(K N)$ was also different from MP in the same way. However, $F_{S T}$ values among them were not high.

Population structure. Population of Hilsa shad belonged two groups $(\mathrm{K}=2)$ was supported by Structure analysis, dominant group (green colored group) belonged to the maximum individuals of the population and only few individuals carrying some genes of other group (red colored group) along with dominant group genes (Fig. 5, Fig. S2, Table S2). Samples of CM, CN, MG, MO and SS belonged to the dominant group without any admixture individuals whereas BG, $\mathrm{BR}, \mathrm{CB}, \mathrm{CF}, \mathrm{CP}, \mathrm{PC}, \mathrm{PG}$ and RS mostly belonged to the dominant group with few admixture individuals. Moreover, BL, KN, MK, MP and PP had more admixture individuals than dominant group individuals (Fig. 5). There was no single location that had only admixture individuals or no one individual that only carried the genes of other small group (red colored group). PCA result is also similar to structure result (Fig. S1). All samples of Bangladesh water including all types of strategic ecosystems make a single cluster that represent only one population is present there. There was no isolation between sea, estuary and freshwater ecosystems and no separate clusters between western and eastern freshwater rivers.

\section{Discussion}

Result of the maximum likelihood IQtree and the population structure suggested that the fresh, estuarine and marine water of Bangladesh have a single population of Hilsa shad (Fig. 3; Fig. 5). In-addition both PCA and network on SNP loci analysis also represented the same trend (Fig. S1, Fig. 4). In the phylogenetic tree, samples of all locations were mixed together without making any specific cluster. In the population structure analysis, a single population was present with some admixture individuals bearing small portion of genes from other group. Pairwise $\mathrm{F}_{\mathrm{ST}}$ value between maximum locations were poor with non-significant $P$ value $(P<0.05)$, that support the deprived local population differences and homogeneity of this fish population throughout our studied locations.

Bangladesh has diversified fresh water habitats for Hilsa shad migration including main river system, coastal and freshwater small rivers, hill stream rivers, haors etc. but anadromous migration of this shad starts from same marine water body, the Bay of Bengal, which is their living ground. Furthermore, this fish has highly migratory nature among marine, estuarine and fresh water bodies. Therefore, it is difficult to draw a conclusion that there is more than one population in this water system. Low variation among groups and among population within groups also did not support more than one population. $\mathrm{F}_{\mathrm{ST}}$ value between most of the locations was poor with non-significant $P$ value, which suggested that the population differences were not significant. Although in some cases, $\mathrm{P}$ value was significant but due to their poor $\mathrm{F}_{\mathrm{ST}}$ value did not provide strong support of local population differences. Present findings of this study were supported by the findings of some previous researchers who represented the single gene pool or stock of this species in the Bay of Bengal with a substantial gene flow ${ }^{18,52,53}$.

All of the spawning grounds of Hilsa shad were identified in the coastal areas of Bangladesh especially at the lower stretches of the Meghna, the Tetulia, the Ander Manik and the Shahabazpur River e.g., Hatia (Moulavir char) Sandwip (Kalir char) and Bhola (Dhal char and Monpura) ${ }^{6,21}$. However, migratory plan is mainly initiated during the spawning season, which is activated with follow of fresh water runoff from the inland rivers, and naturally it occurs with the commencement of the south-west monsoon and consequent flooding of all the major rivers draining down to the upper Bay of Bengal and there are no considerable differences in any context. Isolation of spawning ground is an important factor for population differentiation ${ }^{11}$. Due to presence of un-alienated spawning grounds, it is less feasible to draw population differences of Hilsa shad in the upper streams of different rivers and in their living ground, Bay of Bengal. Therefore, the unique spawning grounds and sole major migratory down-stream route strengthen the presence of single population in all over the Bangladesh water without any significant population clusters. Without specify exact spawning grounds for every cluster, it is unrealistic to draw several clusters in this population. 
Hilsa population studies in Indian part across the Hoogli, the Bhagirathi, the Ganges and the Brahmaputra Rivers also suggested single and genetically homogeneous population in Indian part ${ }^{10,17,18}$. Hilsa shad population of the Hoogli-Bhagirathi river system and Hilsa stock of Bangladesh water used same natal habitat, Bay of Bengal. Moreover, the River Ganges is the upstream of the Padma River (Bangladesh) and the Bhagirathi River (India) as well as the Brahmaputra is the upstream of the Jamuna River (Bangladesh). Most of the Hilsa shad of River Ganges comes from the Padma River and as the same way the Brahmaputra river has no other significant source of this fish except the Jamuna River. So genetic homogeneity and unique population across these rivers of Indian part also supported the Hilsa shad's single population in the Bangladesh water.

Nevertheless, Rahman and Naevdal (2000) based on allozymes and muscle proteins as well as Mazumder and Alam (2009) based on mitochondrial D-loop region figured out more than one Hilsa population in Bangladesh water ${ }^{15,54}$. Rahman and Naevdal (2000) mentioned two populations: 1 . Marine and 2. Estuary and fresh water but they processed without explaining how this highly migratory species was separated into two distinct cohorts. Mazumder and Alam (2009) divided the population into two clusters like previous study but poor pairwise $\mathrm{F}_{\mathrm{ST}}$ value between two groups showed that there were no differences between fresh water and marine-estuarine locations. Recently Asaduzzaman et al. (2020) reported three clusters in the Hilsa population in Bangladesh water, first one was in marine and estuarine waters and another two belonged to north-western riverine (turbid freshwater) and north-eastern riverine (clear freshwater) ecotypes ${ }^{20}$. Existing of a single population, the most likely assumption from the present research varied with their findings. Our result suggested that as a highly migratory species, Hilsa shad is incapable to belong to more than one population when sampled at different sections of their migration route. Our postulation is the presence of single cluster in the Bangladesh water because all water bodies are almost connected to each other, raising high rate of gene flow and created large population size. Western and eastern river systems of Bangladesh have immaterial dissimilar water quality (e.g., turbidity) but this is not enough to make population differences of Hilsa shad since they migrate and start their life from same spawning grounds and used almost same route across the lower stream and coastal estuaries during their breeding migration. Asaduzzaman et al. (2020) reported that samples of the Meghna river (MR) was included in the north-eastern riverine (clear freshwater) ecotypes by PCA and neighbor-joining tree analysis ${ }^{20}$. However, their sample collection site (MR) was located in the common migratory route for north-western riverine (turbid freshwater) and north-eastern riverine (clear freshwater) ecotypes. Therefore, this site should be representing the samples of both ecotypes rather than specific one.

If we draw several specific populations or clusters in the upper streams of Bangladesh that means we had the scope to find this shad in the freshwater all over the year round. However, in the freshwater of Bangladesh, this fish was available in the summer (July-October) and winter season (January-March) only; these were related to their summer and winter migration respectably ${ }^{55}$. If one or two groups of this fish, continue their complete lifecycle in the freshwater (Western/Eastern part of Bangladesh) that states the assurance of continuous supply of this fish almost year round. However, the original scenario does not support this hypothesis. Finally we can conclude that, only one population of this fish inhabit in the Bangladesh water without any instance of different populations and clusters (2-4) but in some specific locations, they had some particular characteristics. The Bay of Bengal is their main living ground, at the time of their breeding they come to the freshwater upper streams, spawn in the estuaries and finally return to the sea. Therefore, using all the same ecosystems (sea, estuary and freshwater rivers) in a cyclic fashion is essential to support their life cycle, which certainly pushes all the individuals to belong a unique population.

In the population structure analysis, only one population of Hilsa shad was identified with some admixture individuals (32\%) containing partial genes from other population in the water bodies of Bangladesh. The mentioned other population might not represent the Hilsa population of the Hoogly and Bhagirathi river system, India because, the Hilsa shads of both migratory routes of Bangladesh and India showed genetic homogeneity ${ }^{10,17}$. The Ganges and Brahmaputra rivers of Indian part are the upstream of the Padma and the Jamuna river of Bangladesh and might be belonged to the same population. However, Hilsa population of the Arabian Sea was genetically heterogeneous from the Bay of Bengal ${ }^{18}$ and those different population genes of admixture individuals might come from the Arabian Sea by oceanographic dispersion. Once (almost 18,000 years ago) the Arabian Sea had a close connection with the Bay of Bengal through the Laccadive Sea, the Gulf of Mannar and the Palk Bay. Therefore, this likely was an easy way for oceanographic dispersion of Hilsa shad between these two water bodies. After that period, a bridge of limestone shoals, coral reefs and tombolo called as 'Ram Bridge' or 'Adam's Bridge' (about $48 \mathrm{~km}$ ) originated between Pamban Island off the south-eastern coast of Tamil Nadu, India, and Mannar Island, off the north-western coast of Sri Lanka 56,57. Sarker et al. (2020) also mentioned that type of oceanographic dispersion between these two water bodies for another Clupeid fish species, Hilsa kelee ${ }^{49}$. The Irrawaddy, the Naaf and the Sittang River of Myanmar were also regarded as another important route for Hilsa migration ${ }^{6,58}$. There is also a possibility of inflowing of these different genes of other population from such population. Still there is no population structure study was conducted in the Myanmar part. Therefore, it is no scope to compare those admixture individuals with the Hilsa population of Myanmar. However, for completing the full scenario, the Hilsa population of Myanmar also claims research attention in population genomics field.

Hill stream river and haor were two important and unique ecosystems for fish diversity in Bangladesh, they belong to the unique characteristics in the ecological factors as well as fish diversity ${ }^{62,63}$. Infrequently Hilsa shad use these two water bodies as their migratory routes. Samples were collected from the Shomeswari River and the Dingapota Haor, Mohanganj as the representatives of hill stream river and haor population respectively. However, Hilsa shad of these two exclusive water bodies were similar to the samples of the some other fresh water bodies (i.e., CM, CN and MG) as they were belonging to the Hilsa population without any admixture individual. Samples of SS do not have any significant $P$ value with other locations whereas MO samples had significant $P$ value with five other locations but having poor $F_{S T}$ value with three locations (i.e., BL, PP, MG). MO samples had only mentionable $F_{S T}$ value with $M P$ (estuarine) and MK (marine), which might be the result of differences in water quality of these two water bodies. In PCA, phylogenetic tree and in network, the samples of hill stream river and haor failed to make any unique cluster or monophyletic clade that represent they are also the part of single unique Hilsa population of Bangladesh water.

Main migration was occurred through the Meghna river estuary, which is connected to the Padma, Meghna and Jamuna river system. However, there are some other alternative routes through some small coastal rivers e.g., the Pashur, the Bishkhali, the Balaswar, the Kocha river, which are connected to the Padma river through the Modhumati and the Gorai river. These coastal rivers passed through or beside the world largest mangrove forest Sundarban. Thus, these two 
routes are ecologically different from each other. Samples of these two routes have some genetic differences, because most of the locations (MK, CF and BL with $\mathrm{PP}$ and $\mathrm{KN}$ ) of these two estuarine routes had significant $\mathrm{P}$ value, but their $\mathrm{F}_{\mathrm{ST}}$ value was not satisfactorily high to make population differences.

Ecological differences of these two routes might be played an important role to create this type of slight differences among them. Therefore, these scenarios were not significant enough to describe noteworthy differences in the population level, but may make a sign of upcoming population differences.

\section{Conclusion}

In conclusion, the Hilsa shad collected from diverse habitats of Bangladesh belonged to the same population without mentionable more clusters. Although, Hilsa shad supply in Bangladesh is almost satisfactory but genetic diversity of this fish was very poor. Because of breeding failure of large group in the breeding migration and changing spawning pattern, the fish might experience a genetic bottleneck recently. This scenario is not a good sign for the survival of this population. Bangladesh, India and Myanmar already took some fisheries management strategy that may increase their number but failed to increase the genetic variation. Therefore, all three coastal countries of the Bay of Bengal should take a joint plan for the fisheries management and conservation of this fish species.

\section{Declarations}

\section{Acknowledgements}

We are grateful to Mr. Biplab Kumer Mandal, Mr. Samar Krishna Garami, Mr. Amit Kumar Neogi, Mr. Md. Jayedul Islam and Mr. Alamin for helping in sample collection. We are also thankful to Miss. Shuli Song, Miss. Irin Sultana and Mr. Roland Nathan Mandal for their technical support. The Shanghai Oceanus Super-Computing Center (SOSC) is also acknowledged for their computational resource support for data analysis.

Conflict of interest. The authors declared that they have no conflict of interest

\section{Declaration of funding}

This work was supported by "Science and Technology Commission of Shanghai Municipality (19410740500)" and "Shanghai Collaborative Innovation for Aquatic Animal Genetics and Breeding project”.

\section{Declaration of animal research ethics approval}

Species used in this study (Hilsa shad: Tenualosa ilisha) is a food fish in Bangladesh. No live fish was used in this study. Samples (dead fish) were taking from commercial fishing boats or directly from fisherman at fish landing. Fish tissue sampling and protocols were approved by the 'Ethics Committee for the Use of Animal Subjects' of Shanghai Ocean University.

\section{Data accessibility}

Gene-capture data with adapters and low-quality reads were deposited in NCBI (PRJNA643346).

Contributions. C.L. and A.S. designed the project and wrote the primary manuscript. M.A.B and A.S. collected samples. A.S. performed lab work, data preparation and analysis. All authors contributed in editing and revising the manuscript.

\section{Orcid}

https://orcid.org/0000-0003-3075-1756

\section{References}

1. Ahsan, D. A., Naser, M. N., Bhaumik, U., Hazra, S. \& Bhattachacharya, S. B. Migration, Spawning Patterns and conservation of Hilsa shad in Bangladesh and India 95 (Academic Foundation: New Delhi, India, 2014)

2. Rahman, M. J., Wahab, M. A., Amin, S. M. N., Nahiduzzaman, M. \& Romano, N. Catch Trend and Stock Assessment of Hilsa Tenualosa ilisha Using Digital Image Measured Length-Frequency Data. Mar Coast Fish. 10, 386-401 (2018)

3. Roberd, A. A., Taha, H., Metali, F., Ahmad, N. \& Arai, T. Validation of occurrence of tropical shads, Tenualosa ilisha (Hamilton,1822) and T.toli (Valenciennes, 1847) (Teleostei, Clupeidae), in Malaysian waters. Check List. 15(1), 65-69; 10.15560/15.1.65 (2019)

4. DOF Yearbook of fisheries statistics of Bangladesh 2017-18. Ministry of Fisheries and Livestock and Department of Fisheries, Dhaka, Bangladesh 35, 1121 (2018)

5. Hossain, M. M. \& Chowdhury, R.M. Hydro-morphological study for rehabilitation of old Madhumati River using mathematical model. / J Eng Sci. 3(1), 1-12 (2012)

6. Hossain, M. A. R. et al. A. Biology and fisheries of Hilsa shad in Bay of Bengal. Sci Tot Environ. 1720-1734; 10.1016/j.scitotenv.2018.10.034 (2019)

7. Benshila, R. et al. The upper Bay of Bengal salinity structure in high resolution model. Ocean Mod. 74, 36-52; 10.1016/j.ocemod.2013.12.001 (2014)

8. Quddus, M. M. A, Shimizu, M. \& Nose, Y. Spawning and fecundity of two types of Hilsa ilisha in Bangladesh waters. Bull Japan Soc Sci Fish. 50(2), 177181 (1984)

9. Bhaumik, U. Migration of Hilsa shad in the IndoPacific region: a review. J Curr Res Acad Rev. 3, 139-155 (2015) 
10. Mohindra, V. et al. Genetic population structure of a highly migratory Hilsa Shad, Tenualosa ilisha, in three river systems, inferred from four mitochondrial genes analysis. Environ Biol Fish. 102, 939-954; 1007/s10641-019-00881-8 (2019)

11. Alvarado J.R. et al. Hierarchical analyses of genetic variation of samples from breeding and feeding grounds confirm the genetic partitioning of northwest Atlantic and South Atlantic populations of swordfish (Xiphias gladius L.). 327 (2) 167-182 (2005)

12. Asaduzzaman, M. et al. Population genomics of an anadromous Hilsa shad Tenualosa ilisha species across its diverse migratory habitats: Discrimination by Fine-Scale Local Adaptation. Genes 11, 46. 10.3390/genes11010046 (2020)

13. Yang, T. Y., Gao, T. X., Meng, W. \& Jiang, Y. L. Genome-wide population structure and genetic diversity of Japanese Whiting Sillago japonica inferred from genotyping-by-sequencing (GBS): implications for fisheries management. Fish Res. 225, 105501; 10.1016/j.fishres.2020.105501 (2020)

14. Madduppa, H. H., Timm, J. \& Kochzius, M. Reduced genetic diversity in Clown Anemonefish Amphiprion ocellaris in exploited reefs of Spermonde Archeopelago, Indonesia. Front Mar Sci. 5, 80 ; 3389/fmars.2018.00080 (2018)

15. Rahman, M. \& Naevdal, G. Population genetic studies of hilsa shad, Tenualosa ilisha (Hamilton), in Bangladesh waters: evidence for the existence of separate gene pools. Fisheries Manag Eco 7, 401-411; 10.1046/j.1365-2400.2000.00211.x (2000)

16. Ahmed, A. S. I., Islam, M. S., Azam, M. S., Khan, M. M. R. \& Alam, M. S. RFLP analysis of the mtDNA D-loop region in Hilsha shad (Tenualosa ilisha) population from Bangladesh. Ind J Fish. 51, 25-31; 10.1111/j.1439-0426.2004.00588.x (2004)

17. Brahmane, M. P., Kundu, S. N., Das, M. K. \& Sharma, A. P. Low genetic diversity and absence of population differentiation of hilsha (Tenualosa ilisha) revealed by mitochondrial DNA cytochrome b region in Ganga and Hooghly rivers. Afr J of Biotech. 12 (22), 3383-3389; 10.5897/AJB2013.12364 (2013)

18. Behera, B. K. et al. Population genetic structure of Indian shad, Tenualosa ilisha inferred from variation in mitochondrial DNA sequences. J Environ Bio. 36 (5), 1193-1197 (2015)

19. Asaduzzaman, M. et al. Fine-scale population structure and ecotypes of anadromous Hilsa shad (Tenualosa ilisha) across complex aquatic ecosystems revealed by NextRAD genotyping. Sci Rep. 9 (16050), 1-14; 10.1038/s41598-019-52465-2 (2019)

20. Asaduzzaman, M. et al. Population genomics of an anadromous Hilsa shad Tenualosa ilisha species across its diverse migratory habitats: Discrimination by Fine-Scale Local Adaptation. Genes 11, 46. 10.3390/genes11010046 (2020)

21. Miah, M. S, Rahman, M. A. \& Halder, G. C. Analytical approach to the spawning ground of hilsa Tenualosa ilisha (Ham.) in Bangladesh water. Ind J Anim Sci. 69(2), 141-144 (1999)

22. Li, C., Hofireiter, M., Straube, N., Corrigan, S. \& Naylor, G..J. Capturing protein-coding genes across highly divergent species. Biotechni. 54 (6), 321-326; 10.2144/000114039 (2013).

23. Rahman, A. S. M. S., Begum, M. H., Reza, H. A., Ahsan, M. N. \& Ahmed, M. S. Molecular characterization of hilsa shads in Bangladesh using Cytochrome C oxidase subunit 1 (CO1) gene. I J Fauna Bio Stud. 5(3),1-5 (2018)

24. Dwivedi, A. K. Differentiating three Indian shades by applying shape analysis from digital images. J Fish Bio. 1-11; 10.1111/jfb.14074 (2019)

25. Meyer, M., \& Kircher, M. Illumina sequencing library preparation for highly multiplexed target capture and sequencing. Cold Spring Harbor Prot. 2010(6), pdb.prot5448; 10.1101/pdb.prot5448 (2010)

26. Yuan, H., Atta, C., Tornabene, L. \& Li, C. Assexon: Assembling exon using gene capture data. Evol Bioinform. 15, 1-13;10.1177/1176934319874792 (2019)

27. Stajich, J. E. et al. The bioperl toolkit: perl modules for the life sciences. Gen Res. 12, 1611-1618; 10.1101/gr.361602 (2002)

28. Edgar, R.C. Search and clustering orders of magnitude faster than BLAST. Bioinform. 26, 2460-2461; 10.1093/bioinformatics/btq461 (2010)

29. Simpson, J. T. \& Durbin, R. Efficient de novo assembly of large genomes using compressed data structures. Gen Res. 22 (2), 549-556; 10.1101/gr.126953.111 (2012)

30. Slater, G. S. \& Birney, E. Automated generation of heuristics for biological sequence comparison. BMC Bioinform. 6, 31; 10.1186/1471-2105-6-31 (2005)

31. Katoh, K., \& Standley, D.M. MAFFT multiple sequence alignment software version 7: improvements in performance and usability. Mol Biol Evol. 30, 772780; 1093/molbev/mst010 (2013)

32. Li, H. \& Durbin, R. Fast and accurate long-read alignment with Burrows-Wheeler transform. Bioinform. 25, 1754-1760;10.1093/bioinformatics/btp698 (2009)

33. Mckenna, et al. The Genome Analysis Toolkit: a MapReduce framework for analyzing next-generation DNA sequencing data. Genome Res. 20, 1297-1303; 10.1101/gr.107524.110 (2010)

34. DePristo, M. A. et al. A framework for variation discovery and genotyping using next generation DNA sequencing data. Nat Gen. 43, 491-498; 10.1038/ng.806 (2011)

35. Nguyen, L. T., Schmidt, H. A., Haeseler, V. A. \& Mingh, B. Q. IQ-Tree: A fast and effective stochastic algorithm for estimating maximum likelihood phylogenies. Mol Biol. 32, 268-274; 1093/molbev/msu300 (2015)

36. Bandelt, H. J., Forster, P. \& Rohl, A. Median-joining networks for inferring intraspecific phylogenies. Mol Bio Evol. 16, 37-48; 10.1093/oxfordjournals.molbev.a026036 (1999)

37. Lischer, H. E. \& Excoffier, L. PGDSpider: An automated data conversion tool for connecting population genetics and genomics programs. Bioinform. 28, 298-299; 10.1093/bioinformatics/btr642 (2012)

38. Excoffier, L., Laval, G. \& Schneider, S. Arlequin (version 3.0): an integrated software package for population genetics data analysis. Evo bioinform on/1, 47-50; 10.1177/117693430500100003 (2005)

39. Rozas, J. et al. DnaSP 6: DNA sequence polymorphism analysis of large data sets. Mol Bio Evo./ 34 (12), 3299-3302; 10.1093/molbev/msx248 (2017) 
40. Weir, B. S., Cockerham C. C. Estimating F-statistics for the analysis of population structure. Evol. 38, 1358-1370; 10.1111/j.1558-5646.1984.tb05657.x (1984)

41. Pritchard, J. K., Stephens, M. \& Donnelly, P. Inference of population structure using multi-locus genotype data. Genetics. 155, 945-959; 10.1111/j.14718286.2007.01758.x (2000)

42. Earl, D.A., \& VonHoldt, B.M. STRUCTURE HARVESTER: A website and program for visualizing STRUCTUREoutput and implementing the Evanno method. Conserv Gen Resour. 4, 359-361; 10.1007/s12686-011-9548-7 (2012)

43. Jombart, T. \& Ahmed, I. Adegenet 1.3-1: New tools for the analysis of genome-wide SNP data. Bioiform. 27, 3070-3071; 10.1093/bioinformatics/btr521 (2011)

44. Wang, Q., Zhang, J., Matsumoto, H., Kim, J. \& Li, C. Population structure of elongate ilisha llisha elongata along the Northwestern Pacific Coast revealed by mitochondrial control region sequences. Fish Sci. 82, 771-785; 10.1007/s12562-016-1018-4 (2016)

45. Cheng, F., Wang, Q., Delser, P. M. \& Li, C. Multiple freshwater invasions of the tapertail anchovy (Clupeiformes: Engraulidae) of the Yangtze River. Eco Evo. 00,1-14; 10.5061/dyrad.2j5b4 (2019)

46. Zheng, W., Zou, L. \& Han, Z. Genetic analysis of the populations of Japanese anchovy Engraulis japonicus from the Yellow Sea and East China Sea based on mitochondrial cytochrome b sequence. Bio chem Syst Ecol. 58, 169-177; 10.1016/j.bse.2014.12.007 (2015)

47. Tonteri, A., Veselov, A. J., Titov, S., Lumme, J. \& Primmer, C. R. The effect of migratory behavior on genetic diversity and population divergence: A comparison of freshwater and anadromous Atlantic salmon (Salmo salar). Fish Bio. 70, 381-398; 10.1111/j.1095-8649.2007.01519.x (2007)

48. Egan, J. P. et al. Phylogenetic analysis of trophic niche evolution reveals a latitudinal herbivory gradient in Clupeoidei (herrings, anchovies, and allies). Mol Phy Evo.124: 151-161; 10.1016/j.ympev.2018.03.011 (2018)

49. Sarker, A. et al. Genetic diversity of Hilsa kelee collected from the Bay of Bengal and the Arabian Sea. Mar Biodivers. 50, 94; 10.1007/s12526-020-01114-3 (2020)

50. Liu, J. X. et al. Effects of Pleistocene climatic fluctuations on the phylogeographic and demographic histories of Pacific herring (Clupeapallashi). Mol Ecol. 20, 3879-3893; 10.1111/j.1365-294X.2011.05213.x (2011)

51. Miah, M. S. Climatic and anthropogenic factors changing spawning pattern and production zone of Hilsa fishery in the Bay of Bengal. Weat Cli Extrem. 7, 109-115; 1016/j.wace.2015.01.001 (2015)

52. Milton, D. A. \& Chenery, S. R. Can otolith chemistry detect the population structre of the shad Hilsa, Tenualosa ilisha? Comparison with the results of genetic and morphological studies. Mar Ecol Prog Ser. 222, 239-251; 3354/meps222239 (2001)

53. Salini, J. P., Milton, D.A., Rahman, M. J. \& Hussain, M. G. Allozyme and morphological variation throughout the geographic range of the tropical shad, hilsa Tenualosa ilisha. Fisheries Res. 66:53-69; 10.1016/S0165-7836(03)00124-3 (2004)

54. Mazumder, S. K. \& Alam, M. S. High levels of genetic variability and differenciation in hilsa shad, Tenualosa ilisha (Clupeidae, Clupeiformes) populations revealed by PCR-RFLP analysis of the mitochondrial DNA D-loop region. Gene Mol Bio. 32(1), 190-196; 1590/S1415-47572009005000023 (2009)

55. Haroon, A. K. Y. Hilsa Shad: fish for the teeming millions new management alternatives are needed for the hilsa young. Shad J. 3:7-10; 10.1111/faf.12278 (1998)

56. GSI. (Rameswaram. Ministry of Earth Sciences, Government of India. 2003)

57. Weerakkody, U. Potential impact of accelerated sea level rise on beaches of Sri Lanka. J Coast Res. 24, 225-242; 10.1007/s11852-009-0084-5 (1997)

58. Bhaumik, U. Stock Profile of Hilsa Shad Population in Bay of Bengal Region: A Review. Inter J Curr Res Acad Rev. 4(6), 22-38 (2016)

59. Jhingran, V. G., \& Natarajan, A. V. A study of the fisheries and fish populations of the Chilka Lake during the period 1957-65. J Ind Fish Soc. 1, 49-126 (1969)

60. Ramakrishnaiah, M. Biology of Hilsa ilisha (Hamilton) from the Chilka lake with an account on its racial status. Ind J Fish. 19, 35-53 (1972)

61. Dwivedi, A. K. Morphometric variations between seasonal migrants of anadromous shad Tenualosa ilsha (Hamilton, 1822) from Hooghly Estuary, India. Mar Fresh Resear. 70, 1427-1435; 10.1071/MF19004 (2019)

62. Chakraborty, B. K. \& Mirza, M. J. A. Status of aquatic resources in Someswari River in northern Bangladesh. Asi Fish Sci. 23, 174-193 (2010)

63. Chowdhury, N. K. et al. Present status of fish biodiversity in wetlands of Tahirpur Upazila under Sunamganj district in Bangladesh. Inter J Fish Aqua. 6(2), 641-645 (2018)

\section{Tables}




\begin{tabular}{|c|c|c|c|c|c|c|c|}
\hline No & Habitat & Sample ID & $\begin{array}{l}\text { Voucher } \\
\text { number }\end{array}$ & Sampling Location & $\begin{array}{l}\text { Water } \\
\text { system }\end{array}$ & $\begin{array}{l}\text { No. of } \\
\text { samples }\end{array}$ & Latitude \\
\hline \multirow[t]{5}{*}{1} & \multirow{5}{*}{$\begin{array}{l}\text { Western } \\
\text { Riverine } \\
\text { (Freshwater) }\end{array}$} & CL1364 & $\begin{array}{l}\text { SoU1801035- } \\
1 \text { to } 8\end{array}$ & Chilmari (CM) & $\begin{array}{l}\text { Brahmaputra } \\
\text { River }\end{array}$ & 8 & $25^{\circ} 35^{\prime} 03.5^{\prime \prime}$ \\
\hline & & CL1350 & $\begin{array}{l}\text { SoU1801036- } \\
\text { 1to } 6\end{array}$ & Balashi Ghat (BG) & $\begin{array}{l}\text { Jamuna } \\
\text { River }\end{array}$ & 6 & $25^{\circ} 23^{\prime} 32.4^{\prime \prime}$ \\
\hline & & CL1348 & $\begin{array}{l}\text { SoU1801034- } \\
1 \text { to } 7\end{array}$ & Chapai-Nababganj (CN) & $\begin{array}{l}\text { Upper } \\
\text { Padma River }\end{array}$ & 7 & $24^{\circ} 36^{\prime} 23.7^{\prime \prime}$ \\
\hline & & CL1349 & $\begin{array}{l}\text { SoU1801037- } \\
1 \text { to } 8\end{array}$ & Rajshahi (RS) & $\begin{array}{l}\text { Upper } \\
\text { Padma River }\end{array}$ & 8 & $24^{\circ} 21^{\prime} 25.4^{\prime \prime}$ \\
\hline & & CL 1365 & $\begin{array}{l}\text { SoU1801038- } \\
1 \text { to } 10\end{array}$ & Manikganj (MG) & $\begin{array}{l}\text { Lower } \\
\text { Padma River }\end{array}$ & 10 & $23^{\circ} 45^{\prime} 40.1^{\prime \prime}$ \\
\hline 2 & $\begin{array}{l}\text { Eastern } \\
\text { Riverine } \\
\text { (Freshwater) }\end{array}$ & CL 1363 & $\begin{array}{l}\text { SoU1801042- } \\
1 \text { to } 10\end{array}$ & Bhairab (BR) & $\begin{array}{l}\text { Upper } \\
\text { Meghna } \\
\text { River }\end{array}$ & 10 & $24^{\circ} 01^{\prime} 57.2^{\prime \prime}$ \\
\hline \multirow[t]{2}{*}{3} & \multirow{2}{*}{$\begin{array}{l}\text { Haor and } \\
\text { hill stream } \\
\text { river }\end{array}$} & CL2317 & $\begin{array}{l}\text { SoU1801040- } \\
1 \text { to } 2\end{array}$ & Mohanganj (MO) & $\begin{array}{l}\text { Dingapota } \\
\text { Haor }\end{array}$ & 2 & $24^{\circ} 52^{\prime} 50.3^{\prime \prime}$ \\
\hline & & CL2318 & $\begin{array}{l}\text { SoU1801041- } \\
1\end{array}$ & Someshwari, Durgapur (SS) & $\begin{array}{l}\text { Someshwari } \\
\text { River }\end{array}$ & 1 & $25^{\circ} 06^{\prime} 31.4^{\prime \prime}$ \\
\hline 4 & $\begin{array}{l}\text { Middle } \\
\text { Meghna }\end{array}$ & CL2026 & $\begin{array}{l}\text { SoU1801039- } \\
1 \text { to } 10\end{array}$ & $\begin{array}{l}\text { Chandpur } \\
\text { (CP) }\end{array}$ & $\begin{array}{l}\text { Lower } \\
\text { Meghna } \\
\text { River }\end{array}$ & 10 & $23^{\circ} 11^{\prime} 42.7^{\prime \prime}$ \\
\hline \multirow[t]{3}{*}{5} & \multirow[t]{3}{*}{$\begin{array}{l}\text { Meghna } \\
\text { Estuary }\end{array}$} & CL2036 & $\begin{array}{l}\text { SoU1801046- } \\
1 \text { to } 10\end{array}$ & Bhola (BL) & $\begin{array}{l}\text { Meghna } \\
\text { River Estuary }\end{array}$ & 10 & $22^{\circ} 46^{\prime} 43.7^{\prime \prime}$ \\
\hline & & CL 1356 & $\begin{array}{l}\text { SoU1801044- } \\
1 \text { to } 9\end{array}$ & Mohipur (MP) & $\begin{array}{l}\text { Lata Chapli } \\
\text { River }\end{array}$ & 9 & $21^{\circ} 51^{\prime} 24.4^{\prime \prime}$ \\
\hline & & CL 1361 & $\begin{array}{l}\text { SOU1801048- } \\
1 \text { to } 8\end{array}$ & Char Fasson (CF) & Tetulia River & 8 & $22^{\circ} 11^{\prime} 12.1^{\prime \prime}$ \\
\hline \multirow[t]{2}{*}{6} & \multirow{2}{*}{$\begin{array}{l}\text { Small } \\
\text { Coastal } \\
\text { Rivers } \\
\text { (Estuary) }\end{array}$} & CL 2002 & $\begin{array}{l}\text { SOU1801043- } \\
1 \text { to } 8\end{array}$ & Khulna (KN) & Pashur River & 8 & $22^{\circ} 19^{\prime} 05.0^{\prime \prime}$ \\
\hline & & CL 1355 & $\begin{array}{l}\text { SoU1801047- } \\
1 \text { to } 9\end{array}$ & Pirojpur (PP) & Kocha River & 9 & $22^{\circ} 33^{\prime} 26.7^{\prime \prime}$ \\
\hline \multirow[t]{4}{*}{7} & \multirow[t]{4}{*}{$\begin{array}{l}\text { Bay of } \\
\text { Bengal }\end{array}$} & CL 1359 & $\begin{array}{l}\text { SoU1801045- } \\
1 \text { to } 7\end{array}$ & Pokhkhir Char (PC) & $\begin{array}{l}\text { Bay of } \\
\text { Bengal }\end{array}$ & 7 & $21^{\circ} 43^{\prime} 40.0^{\prime \prime}$ \\
\hline & & CL 1357 & $\begin{array}{l}\text { SoU1801049- } \\
1 \text { to } 10\end{array}$ & Patharghata (PG) & $\begin{array}{l}\text { Bay of } \\
\text { Bengal }\end{array}$ & 10 & $21^{\circ} 43^{\prime} 58.4^{\prime \prime}$ \\
\hline & & CL2042 & $\begin{array}{l}\text { SoU1801051- } \\
1 \text { to } 9\end{array}$ & Cox's Bazar (CB) & $\begin{array}{l}\text { Bay of } \\
\text { Bengal }\end{array}$ & 9 & $21^{\circ} 18^{\prime} 55.6^{\prime \prime}$ \\
\hline & & CL 1360 & $\begin{array}{l}\text { SoU1801050- } \\
1 \text { to } 7\end{array}$ & Maheshkhali (MK) & $\begin{array}{l}\text { Bay of } \\
\text { Bengal }\end{array}$ & 7 & $21^{\circ} 37^{\prime} 46.8^{\prime \prime}$ \\
\hline
\end{tabular}

Table 1. Sampling localities, number of samples from each site and sampling dates

\begin{tabular}{|lllll|}
\hline Source of variation & d.f. & Sum of squares & Variance components & Percentage of variation \\
\hline $\begin{array}{l}\text { Among } \\
\text { groups }\end{array}$ & 6 & 336 & $0.3669 \mathrm{Va}$ & 0.99 \\
$\begin{array}{l}\text { Among } \\
\text { populations }\end{array}$ & 11 & 464 & $0.3965 \mathrm{Vb}$ & 1.07 \\
$\begin{array}{l}\text { within } \\
\text { groups }\end{array}$ & & & & \\
\hline $\begin{array}{l}\text { Within } \\
\text { populations }\end{array}$ & 260 & 9411 & $36.1970 \mathrm{Vc}$ & 97.93 \\
\hline Total & 277 & 10211 & & \\
\hline
\end{tabular}

Table 2. Results of analysis of molecular variance (AMOVA) 


\begin{tabular}{|lll|}
\hline Code & Population & Theta (per site) from Pi \\
\hline CM & Chilmari & 0.008811 \\
\hline CN & Balashi Ghat & 0.001809 \\
\hline RS & Chapai-Nababganj & 0.005465 \\
\hline SS & Rajshahi & 0.002277 \\
\hline MG & Manikganj & 0.003821 \\
\hline BR & Bhairab & 0.003508 \\
\hline CP & Chandpur & \\
\hline KN & Khulna & 0.005068 \\
\hline PP & Pirojpur & 0.006612 \\
\hline BL & Bhola & 0.001245 \\
\hline MP & Mohipur & 0.004889 \\
\hline CF & Char Fasson & 0.005580 \\
\hline PC & Pokhkhir Char & 0.003514 \\
\hline PG & Patharghata & 0.004328 \\
\hline CB & Cox's Bazar & 0.004756 \\
\hline MK & Maheshkhali & 0.004543 \\
\hline Average & & 0.006501 \\
\hline & & 0.006025 \\
\hline
\end{tabular}

Table 3. Nucleotide diversity ( $\mathrm{Pi})$ of each population

\begin{tabular}{|c|c|c|c|c|c|c|c|c|c|c|c|c|c|c|}
\hline & $B G$ & $\mathrm{CM}$ & $\mathrm{CN}$ & RS & BR & $B L$ & $\mathrm{CF}$ & MP & CB & MK & PC & $P G$ & $\mathrm{KN}$ & $\mathrm{P}$ \\
\hline BG & 0.0000 & & & & & & & & & & & & & \\
\hline $\mathrm{CM}$ & 0.0000 & 0.0000 & & & & & & & & & & & & \\
\hline $\mathrm{CN}$ & 0.0179 & 0.0000 & 0.0000 & & & & & & & & & & & \\
\hline RS & 0.0009 & 0.0035 & 0.0000 & 0.0000 & & & & & & & & & & \\
\hline BR & 0.0000 & 0.0036 & 0.0000 & 0.0000 & 0.0000 & & & & & & & & & \\
\hline$B L$ & 0.0178 & $0.0346 *$ & $0.0446^{*}$ & $0.0278^{*}$ & 0.0104 & 0.0000 & & & & & & & & \\
\hline $\mathrm{CF}$ & 0.0000 & 0.0000 & 0.0000 & 0.0000 & 0.0000 & $0.0225^{\star}$ & 0.0000 & & & & & & & \\
\hline MP & 0.0620 * & $0.0969 *$ & $0.0993^{*}$ & $0.0867^{*}$ & $0.0581^{\star}$ & 0.0002 & $0.0736^{*}$ & 0.0000 & & & & & & \\
\hline CB & 0.0026 & $0.0047 *$ & 0.0000 & 0.0000 & 0.0000 & $0.0299 *$ & 0.0000 & 0.0799* & 0.0000 & & & & & \\
\hline MK & 0.0549 & $0.0434^{\star}$ & $0.0567^{*}$ & $0.0756^{\star}$ & $0.0253^{\star}$ & 0.0128 & $0.0419 *$ & $0.0179 *$ & $0.0278^{*}$ & 0.0000 & & & & \\
\hline PC & 0.0000 & 0.0046 & 0.0000 & 0.0000 & 0.0000 & $0.0176^{\star}$ & 0.0000 & $0.0742^{\star}$ & 0.0000 & 0.0309 & 0.0000 & & & \\
\hline PG & 0.0000 & $0.0135^{\star}$ & 0.0000 & 0.0000 & 0.0000 & $0.0320 *$ & 0.0000 & $0.0745^{\star}$ & 0.0000 & $0.0262^{\star}$ & 0.0000 & 0.0000 & & \\
\hline $\mathrm{KN}$ & 0.0059 & 0.0235 & 0.0193 & 0.0211 & 0.0000 & 0.0027 & 0.0061 & $0.0359 *$ & 0.0162 & 0.0127 & 0.0127 & 0.0023 & 0.0000 & \\
\hline PP & $0.0257^{\star}$ & $0.0782^{\star}$ & $0.0588 *$ & $0.0545^{\star}$ & 0.0350 * & $0.0042^{\star}$ & $0.0457^{*}$ & $0.0085^{\star}$ & $0.0409 *$ & 0.0000 & $0.0351^{*}$ & $0.0514^{\star}$ & 0.0131 & 0. \\
\hline MG & 0.0111 & $0.0073^{\star}$ & 0.0000 & 0.0000 & 0.0000 & $0.0466^{\star}$ & 0.0000 & $0.1129 *$ & 0.0000 & $0.0704 *$ & 0.0000 & 0.0050 & $0.0359 *$ & 0. \\
\hline MO & 0.1123 & 0.0081 & 0.0000 & 0.0673 & 0.0025 & $0.0360 *$ & 0.0423 & $0.1164^{\star}$ & 0.0013 & $0.1043^{*}$ & 0.0180 & 0.0085 & 0.0730 & 0. \\
\hline SS & 0.0572 & 0.0000 & 0.0000 & 0.0530 & 0.0000 & 0.0000 & 0.0000 & 0.0538 & 0.0000 & 0.0865 & 0.0000 & 0.0000 & 0.0281 & 0. \\
\hline $\mathrm{CP}$ & 0.0000 & 0.0000 & 0.0000 & 0.0000 & 0.0000 & $0.0106^{*}$ & 0.0000 & $0.0643^{\star}$ & 0.0000 & $0.0344^{\star}$ & 0.0000 & 0.0000 & 0.0004 & 0. \\
\hline
\end{tabular}


Table 4. Pairwise differences (FST) among populations

For abbreviations of population names, see Table 1

*Indicates significant $P$ values $(P<0.05)$

\section{Figures}

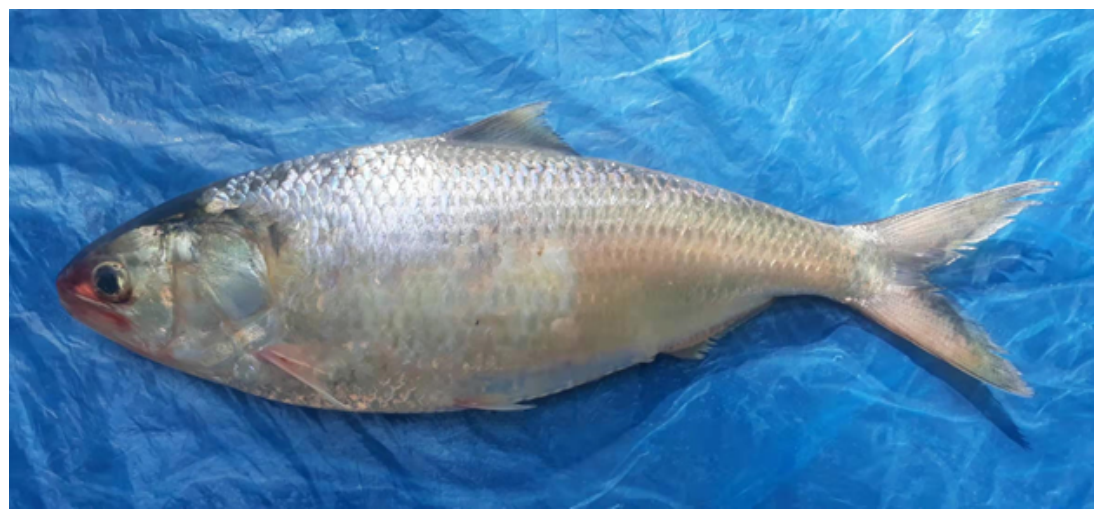

\section{Figure 1}

A Hilsa shad (Tenualosa llisha) specimen collected from Chandpur (CP), Bangladesh

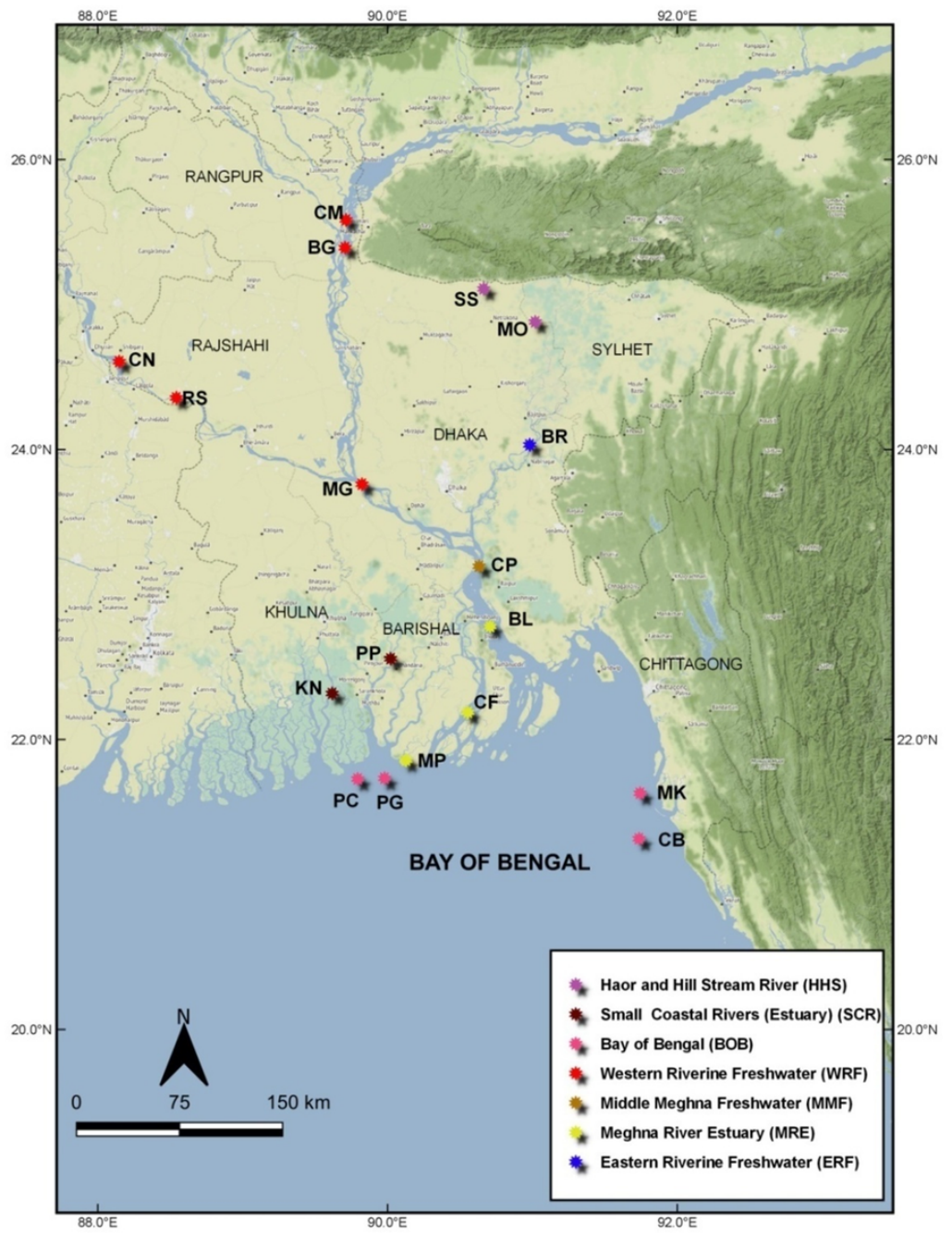

Figure 2 
Map of sample collection sites of the highly migratory Hilsa shad across its diverse migratory habitats including all strategic aquatic ecosystems in Bangladesh. Each color indicates specific habitat group and abbreviated letter indicates sampling location. CM, Chilmari; BG, Balashi Ghat; CN, ChapaiNababganj; RS, Rajshahi; MO, Mohanganj; SS, Someshwari, Durgapur; MG, Manikganj; BR, Bhairab; CP, Chandpur ; KN, Khulna; PP, Pirojpur; BL, Bhola; MP, Mohipur; CF, Char Fasson; PC, Pokhkhir Char; PG, Patharghata; CB, Cox's Bazar; MK, Maheshkhali. Note: The designations employed and the presentation of the material on this map do not imply the expression of any opinion whatsoever on the part of Research Square concerning the legal status of any country, territory, city or area or of its authorities, or concerning the delimitation of its frontiers or boundaries. This map has been provided by the authors.

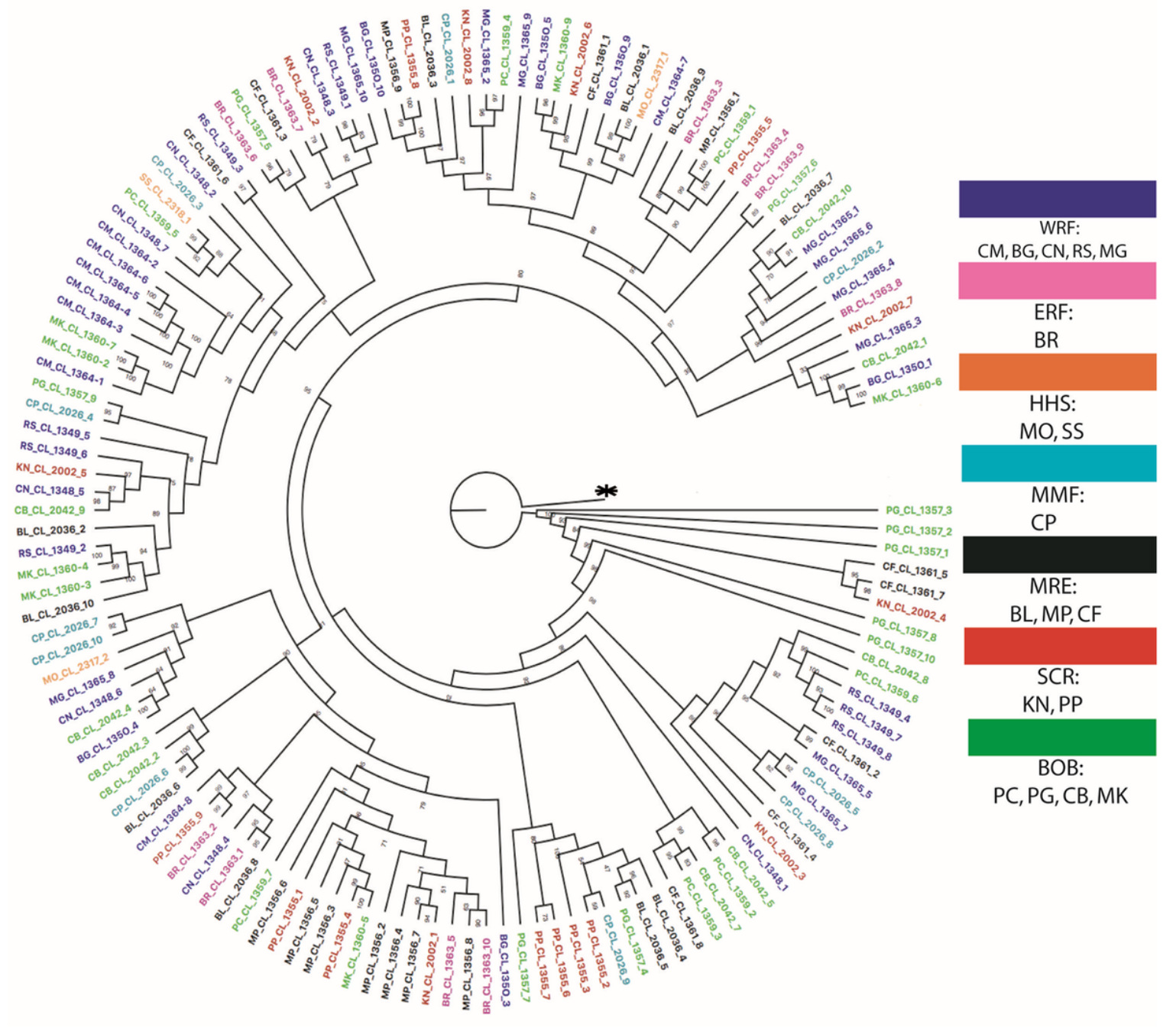

Figure 3

A ML tree based on sequences data concatenating 2,461 loci reconstructed by using IQtree v1.6.9 with 1,000 bootstrap replicates. Each color indicates specific habitat group and abbreviated letter indicates sampling location (Table 1). CM, Chilmari; BG, Balashi Ghat; CN, Chapai-Nababganj; RS, Rajshahi; MO, Mohanganj; SS, Someshwari, Durgapur; MG, Manikganj; BR, Bhairab; CP, Chandpur ; KN, Khulna; PP, Pirojpur; BL, Bhola; MP, Mohipur; CF, Char Fasson; PC, Pokhkhir Char; PG, Patharghata; CB, Cox's Bazar; MK, Maheshkhali. 


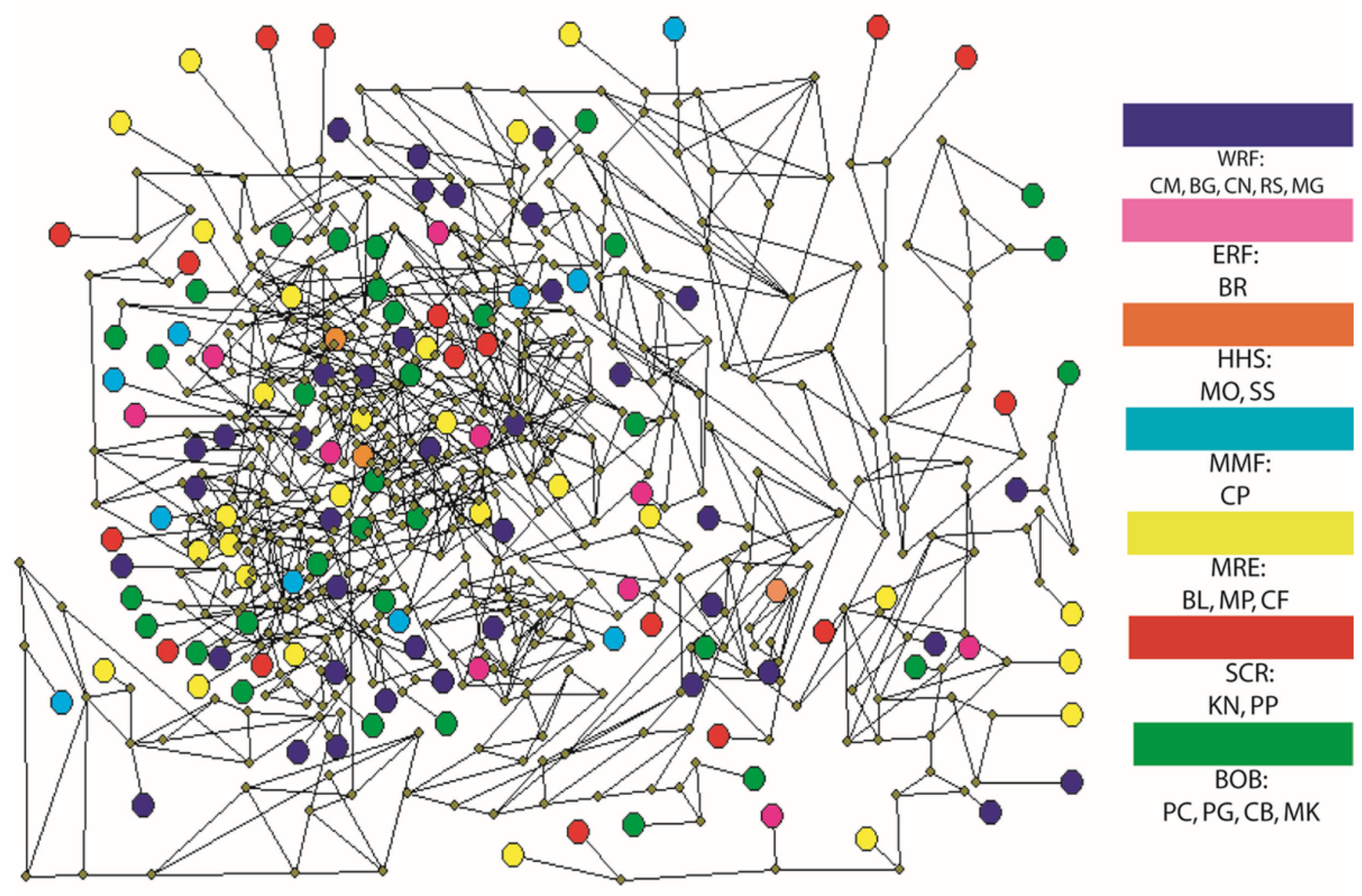

Figure 4

A median joining network of studied individuals based on 842 SNP loci by Network 5.0.1.1. Each color indicates specific habitat group and abbreviated letter indicates sampling location. CM, Chilmari; BG, Balashi Ghat; CN, Chapai-Nababganj; RS, Rajshahi; MO, Mohanganj; SS, Someshwari, Durgapur; MG, Manikganj; BR, Bhairab; CP, Chandpur ; KN, Khulna; PP, Pirojpur; BL, Bhola; MP, Mohipur; CF, Char Fasson; PC, Pokhkhir Char; PG, Patharghata; CB, Cox's Bazar; MK, Maheshkhali. 


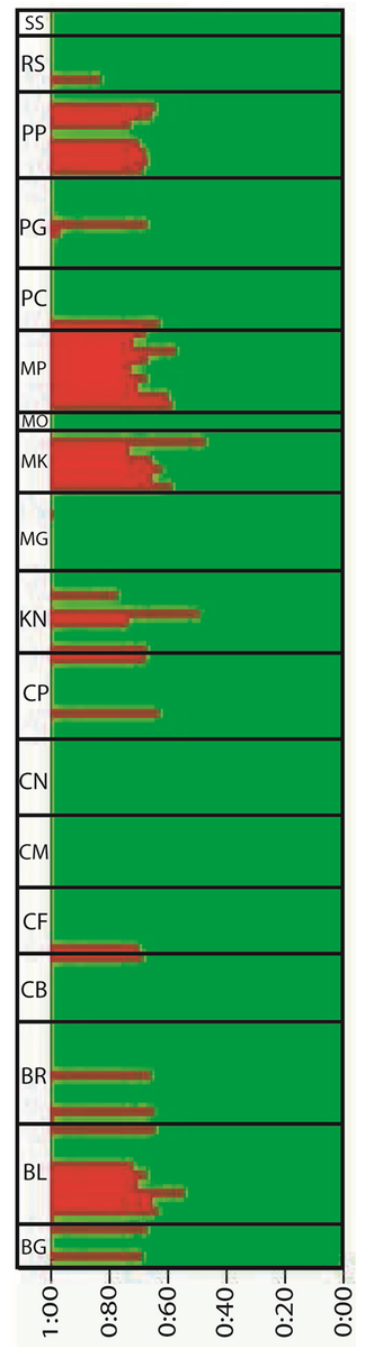

\section{Figure 5}

Structure analysis based on 842 SNP loci. Each color indicates specific habitat group and abbreviated letter indicates sampling location. CM, Chilmari; BG, Balashi Ghat; CN, Chapai-Nababganj; RS, Rajshahi; MO, Mohanganj; SS, Someshwari, Durgapur; MG, Manikganj; BR, Bhairab; CP, Chandpur ; KN, Khulna; PP, Pirojpur; BL, Bhola; MP, Mohipur; CF, Char Fasson; PC, Pokhkhir Char; PG, Patharghata; CB, Cox's Bazar; MK, Maheshkhali.

\section{Supplementary Files}

This is a list of supplementary files associated with this preprint. Click to download.

- Sarkeretal.supplementary.docx 